\title{
О.Н. Николаева
}

\section{О СИСТЕМНОМ КАРТОГРАФИРОВАНИИ БИОЛОГИЧЕСКИХ РЕСУРСОВ ДЛЯ ОБОСНОВАНИЯ РАЦИОНАЛЬНОГО ПРИРОДОПОЛЬЗОВАНИЯ АДМИНИСТРАТИВНОГО СУБЪЕКТА НА ПРИМЕРЕ НОВОСИБИРСКОЙ ОБЛАСТИ}

\begin{abstract}
АННОТАЦИЯ
В статье рассмотрены вопросы систематизачии, моделирования и предоставления пользователям данных о биологических ресурсах административного субъекта. Сформулирована проблема, заключающаяся в необходимости обеспечения региональных органов государственной власти актуальными данными о биологических ресурсах и удобным инструментарием для их анализа. Обоснована необходимость анализа комплекса разнородных данных о биологических ресурсах (кадастровых, мониторинга, отчетности природопользователей и пр.) во взаимосвязи с ландшафтообразующими параметрами окружающей средьл. Предложен инструментарий, позволяющий сотрудникам государственных органов в области управления природопользованием создавать систему картографических моделей биологических ресурсов (система КМБР), моделирующих характеристики биологических ресурсов для решения прикладных задач. Сформулирована цель создания этой системы, определена её целевая аудитория. Изложены принципы картографической визуализации информации в системе КМБР. Охарактеризованы источники исходных данных для создания системы КМБР, включающие материаль государственных кадастров, мониторинга и статистического учёта растительных и фаунистических ресурсов. Обоснован масштабный ряд КМБР, состоящий из двух групп масштабов для картографирования территории региона в целом и единиц его внутреннего административного деления. Раскрыты особенности картографического моделирования и визуализации рельефа в системе КМБР с учётом требований, предъявляемых российским законодательством к открытым картографическим данным. Рассмотрены формы картографической визуализачии данных, запроченных пользователями при обращении к системе КМБР. Представлены примеры картографических моделей лесных ресурсов Новосибирской области, визуализированные в различных формах представления (иифровые карты, трёхмерные модели местности, картографическая анимация). Сделаны выводы о характере практических задач, решение которых оптимизируется благодаря использованию системь КМБР.
\end{abstract}

\section{КЛЮЧЕВЫЕ СЛОВА:}

картографирование природных ресурсов, биологические ресурсы, региональное природопользование, управление природопользованием, картографические модели

\section{ВВЕДЕНИЕ}

Биологические ресурсы являются материальной базой для функционирования широкого спектра отраслей народного хозяйства и вследствие этого активно эксплуатируются человеком. Однако при этом предметом детального исследования и мониторинга остаётся лишь достаточно узкий перечень подвидов биологических ресурсов (в основном лесных и охотничье-промысловых), которые используются непосредственно в экономике. При этом не принимается во внимание состояние целого ряда биологических компонентов и характеристик,

\footnotetext{
${ }^{1}$ Сибирский государственный университет геосистем и технологий (СГУГиТ); 630108, Россия, Новосибирск, ул. Плахотного, 10; e-mail: onixx76@mail.ru
} 
которые оказывают косвенное, но заметное влияние на организацию природопользования в пределах региона и на состояние местных экосистем и окружающей среды в целом.

Развитие современных геоинформационных технологий предоставляет обширные возможности как в области анализа и моделирования данных о конкретном природном ресурсе или группе ресурсов с учётом ландшафтообразующих параметров окружающей среды [Бешенцев, 2011], так и в области предоставления специалистам органов государственной власти удобного доступа к собранным данным и результатам их анализа [Котельникова и др., 2008]. Более того, совершенствование технологий интерактивного доступа к картографическим геопорталам и ГИС-сервисам даёт возможность пользователям, не имеющим специальной подготовки в области картографии, самостоятельно создать картографический продукт, адаптированный под решение конкретной практической задачи [Лисицкий, 2012; Николаева. Об алгоритмизации..., 2015]. С учётом сказанного, для эффективного и рационального использования биологических ресурсов необходимо обеспечить органы государственной власти актуальными данными и удобным, понятным инструментарием, позволяющим анализировать собранные данные во взаимосвязи с ландшафтообразующими параметрами окружающей среды.

\section{Постановка проблемы}

Для решения поставленной задачи предлагается система картографических моделей биологических ресурсов (система КМБР), целью которой является визуализация и моделирование данных о биологических ресурсах административного субъекта на цифровой основе, сформированной на основании современных базовых пространственных данных во взаимосвязи с ресурсами абиотического происхождения для эффективного использования биологических ресурсов. Целевой аудиторией системы КМБР являются специалисты региональных и местных органов государственной власти, занятых планированием, осуществлением и регуляцией природопользования на конкретной территории. Информационное наполнение системы КМБР формируется прежде всего за счёт официальных, регулярно обновляемых источников данных, таких как кадастры, мониторинг и статистический учёт видов флоры и фауны, вносящих наибольший вклад в природопользование субъекта.

\section{МАТЕРИАЛЫ И МЕТОДЫ ИССЛЕДОВАНИЯ}

Проектирование системы КМБР опирается на принципы системного подхода, картографического метода исследования, приёмы геоинформационного анализа и цифрового картографирования. Картографическая визуализация информации осуществляется в соответствии со следующими принципами:

1. Четкое разграничение картографических моделей в зависимости от объекта картографирования (флора или фауна). Сопоставимость моделей обеспечит использование одной и той же общегеографической основы.

2. Учёт состояния биологических ресурсов, косвенно влияющих на характер и особенности природопользования региона (размещение и характеристики охраняемых видов, видов-вредителей, видов, являющихся объектами народного промысла).

3. Обязательный показ политических и административных границ и зон ограничений для выявления конфликтов между местообитаниями человека и биологических видов, являющихся объектами природопользования.

\section{РЕЗУЛЬТАТЫ ИССЛЕДОВАНИЙ И ИХ ОБСУЖДЕНИЕ}

Использование современных классификаций природных ресурсов, принятых в ресурсоведении [Реймерс, 1990], а также учёт существующих схем учёта биологических ресурсов, принятых при ведении их кадастра и мониторинга [Положение..., 1995; Положение..., 1997; О порядке ведения..., 1996; О порядке выполнения..., 2013], позволили сформировать следующую структуру системы КМБР региона (см. рисунок 1). 
Система картографических моделей биологических ресурсов

\begin{tabular}{|c|c|}
\hline $\begin{array}{l}\text { Картографические модели } \\
\text { растительных ресурсов }\end{array}$ & $\begin{array}{l}\text { Картографические модели } \\
\text { фауннстических ресурсов }\end{array}$ \\
\hline $\begin{array}{c}\text { Картографические } \\
\text { модели лесньх ресvосов }\end{array}$ & $\begin{array}{c}\text { Картографические модели } \\
\text { средообразуюших видов и среды их обитания }\end{array}$ \\
\hline $\begin{array}{c}\text { Картографические } \\
\text { модети нелесньхх ресурсов }\end{array}$ & $\begin{array}{c}\text { Картографические модели } \\
\text { охотничье-промысловых видов }\end{array}$ \\
\hline \multirow{2}{*}{$\begin{array}{c}\text { Картографические } \\
\text { модели растительных ресурсов особо } \\
\text { охраняемых природных территорий }\end{array}$} & $\begin{array}{c}\text { Картографические } \\
\text { модели охраняемых видов }\end{array}$ \\
\hline & $\begin{array}{c}\text { Картографические } \\
\text { модели условно вредных видов }\end{array}$ \\
\hline
\end{tabular}

Рисунок 1. Структура системы КМБР

Figure 1. The structure of system of biological resources' cartographic models (BRCM)

Информационное наполнение системы КМБР на территорию административного субъекта подразумевает интеграцию следующих источников разнородных данных о биологических ресурсах [Николаева «О разработке...», 2015]:

- цифровая общегеографическая основа, актуализированная по данным Публичной кадастровой карты Росреестра;

- данные дистанционного зондирования среднего пространственного разрешения, полученные в видимом диапазоне;

- планы лесоустройства на территорию субъекта и его районов;

- отчётные данные регионального Департамента природных ресурсов и охраны окружающей среды о количественных характеристиках лесов и показателях использования лесных ресурсов;

- данные о ландшафтном районировании территории (ранее изданные произведения регионального ландшафтного картографирования);

- статистические данные учёта охотничьих животных, проводимого ФГУ «Центрохотконтроль» при Министерстве сельского хозяйства РФ;

- статистические отчетные данные лесопатологического мониторинга, проводимого Федеральным агентством лесного хозяйства при Министерстве природных ресурсов РФ;

- данные Красных книг РФ и административного субъекта, представленные в виде картографических материалов, сопровождающих видовые очерки;

- данные эпизоотического мониторинга вредителей сельского хозяйства, проводимого ФГБУ «Россельхозцентр» при Министерстве сельского хозяйства РФ;

- данные отчётности охотничьих хозяйств по форме 2ТП (охота), собираемые Федеральной службой государственной статистики РФ.

По территориальному охвату создаваемые КМБР подразделены на региональные, отображающие состояние растительных и фаунистических ресурсов в пределах административного субъекта в масштабах от 1:1 000000 до 1:12 000 000, и топические, создаваемые на отдельные административные районы в масштабах от 1:200 000 до 1:1 000000 для конкретизации сведений о биологических ресурсах. 
При создании системы КМБР необходимо уделить особое внимание отображению рельефа местности. Рельеф оказывает большое влияние на состояние и условия эксплуатации биологических ресурсов: он обусловливает особенности увлажнения и инсоляции местности, что сказывается на высоте древостоя и качестве древесины; глубина расчленения и крутизна склонов влияют на технологические особенности, техническую сложность и стоимость проведения лесозаготовительных работ и мероприятий по обустройству объектов лесной инфраструктуры; степень горизонтального и вертикального расчленения, а также крутизна скатов формируют различные условия для обитания определенных видов животных, а также обусловливают транспортную доступность территории и удобство её использования для организации охотничьего хозяйства [Николаева. Создание..., 2015]. Вместе с тем, как показывает практика хозяйствования, необходимость в детальной информации об абсолютных отметках рельефа местности возникает только на стадии разработки проектов конкретных инженернотехнических сооружений (лесных дорог, линий электропередач, охотничьих и туристских баз и пр.). Эти проекты, как и любые другие, обосновываются по данным топографической съёмки, с привлечением КМБР лишь на начальной стадии обсуждения проекта и выбора приблизительного места (или нескольких возможных мест) его реализации. В большинстве случаев при стратегическом и тактическом планировании использования биологических ресурсов более важной является информация об относительных показателях рельефа: крутизне и экспозиции склонов, вертикальном и горизонтальном расчленении и т. п.

Способ горизонталей, традиционно используемый для отображения рельефа на картах, сконцентрирован на передаче абсолютных отметок, и в меньшей степени ориентирован на отображении общего облика рельефа и его морфометрических характеристик. Это затрудняет пользователю КМБР восприятие информации о рельефе и выявление его влияния на состояние природных ресурсов. Поэтому в том случае, если пользователь требует показа рельефа на КМБР, целесообразно реализовать её в форме цифровой модели местности. Поскольку система картографических моделей биологических ресурсов административного субъекта предназначена для широкого круга пользователей, создание картографических моделей, входящих в её состав, необходимо осуществлять с соблюдением требований, предъявляемых российским законодательством к открытым картографическим данным. В соответствии с этими требованиями [Перечень..., 2000] рельеф на картографических произведениях для широкого круга пользователей должен отображаться способами, не позволяющими определить координаты точек местности точнее 30 м по высоте. Поэтому цифровые модели рельефа для трёхмерного моделирования данных о биологических ресурсах целесообразно создавать на основе карт масштабов 1:200 000 и 1:1 000 000, которые в соответствии с [Основные положения...] отнесены к обзорно-топографическим. Для региональных трёхмерных КМБР целесообразно использовать обзорно-топографическую карту масштаба 1:1 000000 с высотой сечения рельефа 50 м, а для топических - обзорно-топографическую карту масштаба 1:200 000, на которой цифрование каждой второй горизонтали даст высоту сечения рельефа в $40 \mathrm{M}$.

Процедура создания конкретной картографической модели при обращении пользователя с запросом к системе КМБР выполняется в соответствии с принципами формализации создания картографических произведений для широкого круга пользователя [Дышлюк и др., 2011]. Действия пользователя сводятся к выбору подвида биологических ресурсов, которые будут картографироваться, выбору перечня картографируемых показателей и заданию формы визуализации результирующего картографического произведения. Основная часть картографо-составительских и оформительских работ по созданию КМБР в ответ на пользовательский запрос выполняется в автоматизированном режиме, с использованием разработанных принципов автоматизированного проектирования и оформления картографических моделей природных ресурсов [Николаева. Об интерактивном создании..., 2015; Николаева. Об алгоритмизации..., 2015]. 
Созданные КМБР предоставляются пользователям в следующих формах:

1) Двухмерная статичная визуализация в виде растровой или векторной карты. Эта форма представления может быть востребована теми пользователями, которые уже имеют навыки использования картографических произведений в своей профессиональной деятельности. Пример подобной КМБР приведен на рисунке 2.

\section{Общая характеристика эксплуатационных лесов Новосибирской области}

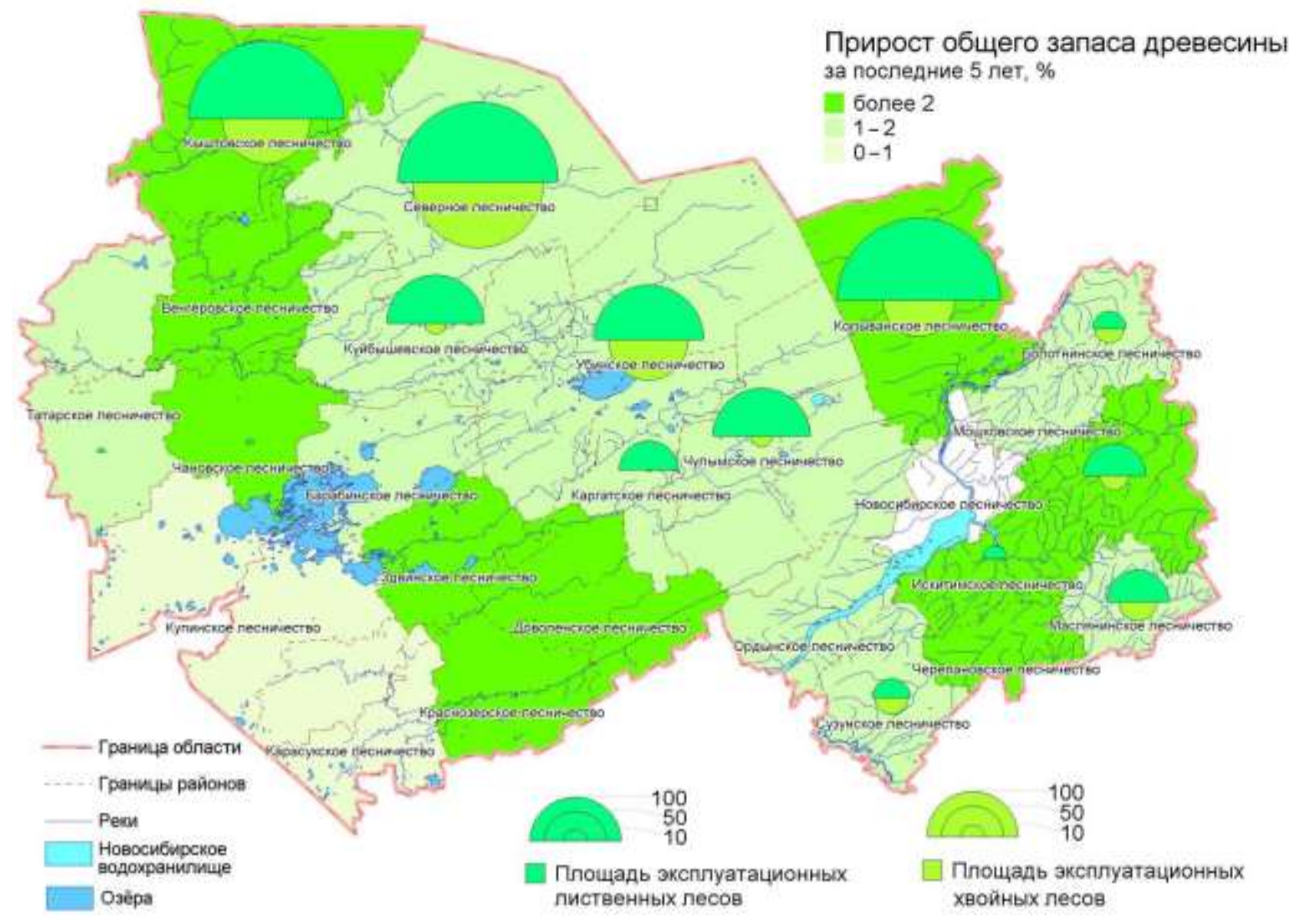

Рисунок 2. Двухмерная статичная визуализаџия КМБР

Figure 2. 2-dimensional static visualization of BRCM

2) Двухмерная динамичная визуализация в виде картографической анимации. Данная форма представления целесообразна при моделировании пространственной или временной динамики показателей состояния или использования биологических ресурсов. Например, на рисунке 3 представлены ключевые кадры анимации, сформированной в ответ на пользовательский запрос об изменении численности лося по районам Новосибирской области в результате охоты в зимний период. 


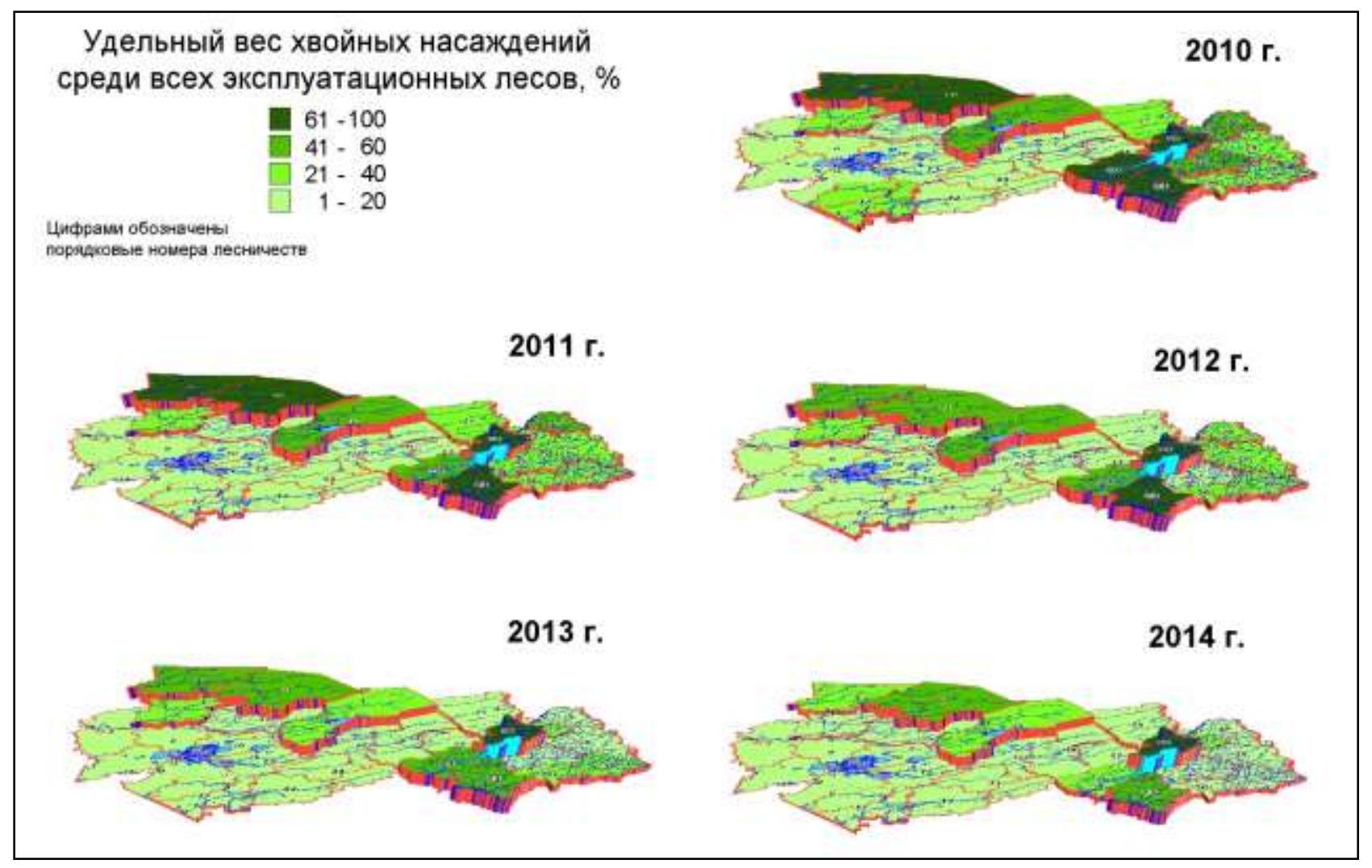

Рисунок 3. КМБР, визуализированная в виде картографической анимации (покадровое отображение)

Figure 3. BRCM as cartographic animation (frame-by-frame display)

3) Трёхмерная статичная картографическая модель, отображающая взаимосвязь рельефа с запрошенными тематическими показателями. На рисунке 4 представлена картографическая модель, на которой выделены берёзовые и сосновые лесонасаждения, произрастающие на южных (с экспозицией от $135^{\circ}$ до $225^{\circ}$ ) склонах и вследствие лучшей инсоляции обладающие более высокими таксационными параметрами (средняя высота, средний диаметр, средний и текущий прирост и т. п.). Поскольку при традиционной компоновке, когда север находится в верхней части картографического изображения, южные склоны, удалённые от зрителя, частично заслоняются формами рельефа, находящимися на переднем плане, в данном случае применена нестандартная компоновка с поворотом картографического изображения на $90^{\circ}$, когда север находится не в верхней, а в левой части изображения. 


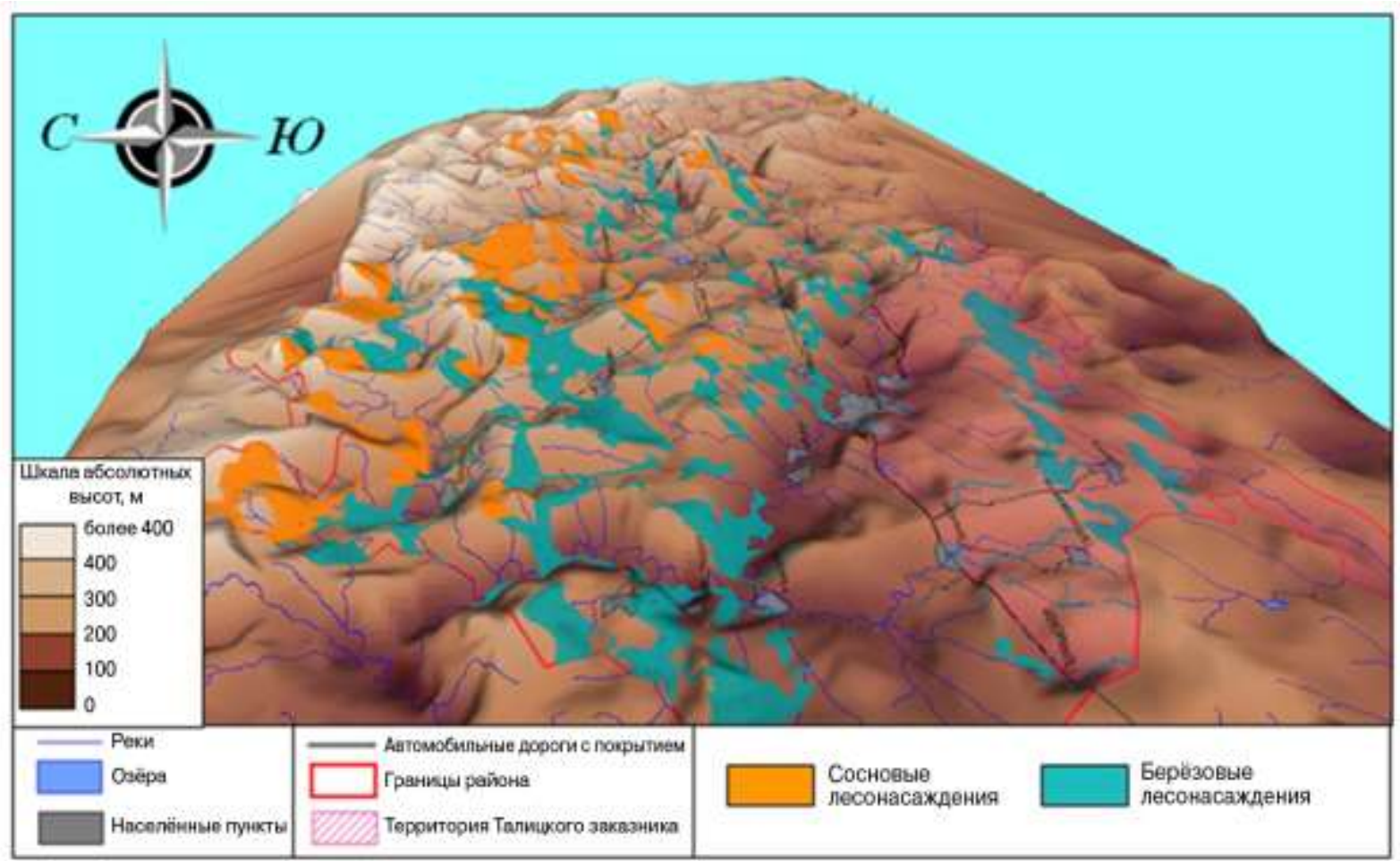

Рисунок 4. КМБР, отображающзая взаимосвязь экспозиции склонов и пород лесонасаждений Маслянинского района Новосибирской области

Figure 4. BRCM of interrelation of slope and tree species exposition

4) Трёхмерная динамичная картографическая модель биологических ресурсов, реализованная в виде 3D-сцены. C точки зрения технической и технологической реализации, это самая сложная форма представления картографических моделей, однако она позволяет пользователю виртуально перемещаться по моделируемой территории для более детального ознакомления с состоянием ресурса на отдельных участках местности и установления локальных взаимосвязей картографируемых показателей с параметрами рельефа. На рисунке 5 приведены ключевые кадры картографической модели, отображающей категории охотничьих хозяйств Маслянинского района Новосибирской области. 

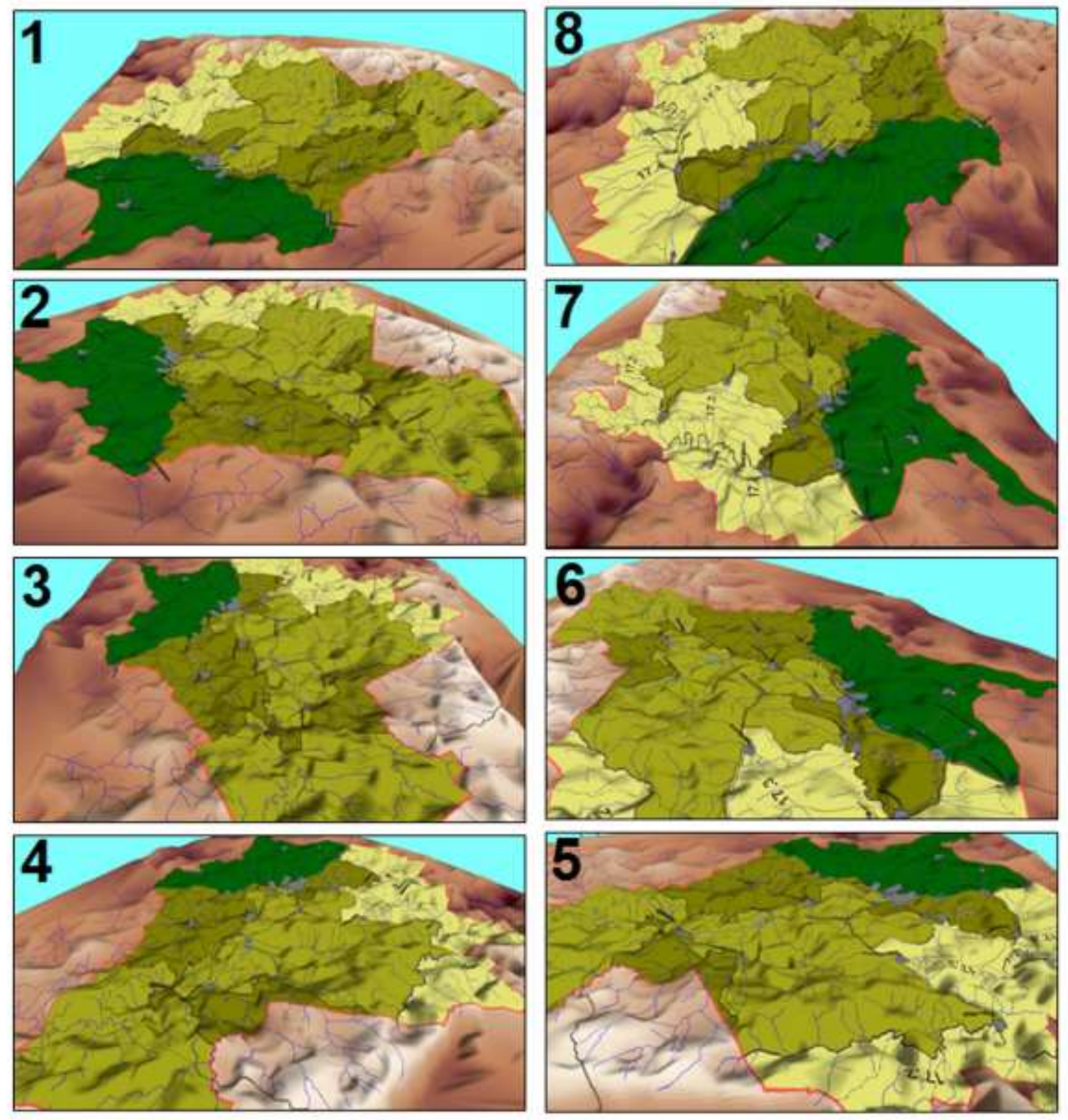

$$
\begin{aligned}
& \text { Статус охотхозяйств Маслянинского района Новосибирской области } \\
& \text { [ планируемые общедоступные охотугодья } \\
& \text { общедоступные охотугодья }
\end{aligned}
$$

Рисунок 5. КМБР, реализованная в виде 3D-видеосиены (представлена последовательность ключевых кадров при панорамном облёте территории)

Figure 5. BRCM as 3D-videoscene (frame-by-frame display of panoramic overfly)

\section{ВЫВОДЫ}

Система КМБР административного субъекта обеспечивает решение следующих задач:

- сбор, систематизация и интеграция разнородных данных о биологических ресурсах, собираемых из различных источников (прежде всего - из официальных источников, характеризующихся регулярным обновлением, таких как материалы кадастров и мониторинга различных компонентов флоры и фауны); 
- предоставление пользователю доступа к собранным данным; возможность осуществления селекции и геоинформационного анализа запрошенных данных для решения конкретных задач по использованию или восстановлению биологических ресурсов административного субъекта;

- создание по запросу пользователя картографического обеспечения, наглядно отображающего запрошенные данные или результаты их геоинформационного моделирования для планирования природопользования и корректуры существующих схем территориального планирования.

Методологические основы создания описанной системы КМБР административного субъекта могут использоваться для создания подобных систем, характеризующих состояние и использование иных ресурсов природных компонентов (водных, минеральных и т. п.) и связанных между собой общими принципами сбора и систематизации исходных данных, единой цифровой картографической основой, кругом решаемых прикладных задач. Такой подход обеспечит получение комплексной характеристики природных ресурсов административного региона [Николаева, 2016].

\section{СПИСОК ЛИТЕРАТУРЫ}

1. Бешенцев А.Н. Геоинформационное обеспечение мониторинга трансформации природных ландшафтов в бассейне оз. Байкал на основе ретроспективных картографических материалов // Аридные экосистемы. - 2011. - № 4 (49). - С. 53-62.

2. Котельникова Н.В., Мазуров С.Ф., Пластинин Л.А. Задачи геоинформационного обеспечения органов власти, хозяйства, образования и бизнеса в Байкальском регионе Сибири // ГЕО-Сибирь: IV Междунар. науч. конгр.: сб. материалов в 5 т. (Новосибирск, 22-24 апреля 2008 г.). - Новосибирск: СГГА, 2008. - Т. 1, ч. 2. - С. 133-136.

3. Лисиикий Д.В. Инструментальная справочно-аналитическая ГИС - новый геоинформационный инструмент для широкого круга пользователей // Интерэкспо ГеоСибирь. 2012. - Т. 1. - С. 213-219.

4. Николаева О.Н. Об интерактивном создании картографического обеспечения для управления природопользованием // Теоретические и прикладные аспекты современной науки : сб. науч. трудов по материалам IX Междунар. научно-практ. конференции, 31 марта 2015 г. / Под общ. ред. М.Г. Петровой. - Белгород: ИП Петрова М.Г., 2015. - Ч. 2. - C. 10-15.

5. Николаева О.Н. О разработке картографического обеспечения для эффективного управления лесными ресурсами // Геодезия и картография. - 2015. - № 11. - С. 30-34.

6. Реймерс Н.Ф. Природопользование. Словарь-справочник. - М.: Мысль, 1990. - 639 с.

7. Положение о лесном мониторинге. Письмо Федеральной службы лесного хозяйства РФ от 29 нояб. 1995 г. № МГ-1-17-6/287 [Электронный ресурс]. - Режим доступа: http://www.businesspravo.ru/Docum/DocumShow_DocumID_35821.html.

8. Положение о лесопатологическом мониторинге [Электронный ресурс]. - Режим доступа: http://docs.cntd.ru/document/901742572.

9. О порядке ведения государственного учёта, государственного кадастра и государственного мониторинга объектов животного мира: Постановление Правительства РФ от 10 ноября 1996 г. № 1342 // Собрание законодательства Российской Федерации. 1996 г. - № 47. - Ст. 5335.

10. О порядке выполнения функции официального статистического учёта территориальными управлениями Росрыболовства [Электронный ресурс]: приказ Федерального агентства по рыболовству от 9 апреля 2013 г. № 254. - Режим доступа: http://docs.pravo.ru/document/view/35469838/40903452/.

11. Перечень объектов местности и элементов содержания топографических карт и планов, запрещённых для открытого опубликования. Утверждён приказом Роскарто- 
графии от 14.12.2000 г. № 181пр. (согласован с ГШ ВС РФ, № 320/2/2996 от 02.11 .2000 г.)

12. Основные положения по созданию и обновлению топографических карт масштабов 1:10000, 1:25000, 1:50000, 1:100000, 1:200000, 1:500000, 1:1000000. - М.: Главное управление геодезии и картографии при Совмине СССР. - 1984. - 81 с.

13. Дышилюк С.С., Николаева О.Н., Ромашова Л.А. Научно-методические основы формализации процессов составления тематических карт для реализации инструментальной справочно-аналитической геоинформационной системы // Вестник СГГА. - 2011. Вып. 1 (14). - С. 49-54.

14. Николаева О.Н. Об алгоритмизации проектирования оформления тематических картографических произведений (на примере картографических моделей природных ресурсов) // Вестник СГУГиТ. - 2015. - Вып. 4 (32). - С. 61-69.

15. Николаева О.Н. О проектировании тематического содержания системы цифровых картографических моделей природных ресурсов региона // Геодезия и картография. 2016. - № 7. - С. 33-38.

\title{
Olga N. Nikolaeva ${ }^{1}$
}

\section{ABOUT SYSTEM MAPPING OF BIOLOGICAL RESOURCES FOR SUBSTANTIATION OF ENVIRONMENTAL MANAGEMENT OF THE ADMINISTRATED UNIT ON THE EXAMPLE OF NOVOSIBIRSK REGION}

\begin{abstract}
The article considers the issues of systematization, modeling and presentation of regional biological resources data. The problem of providing regional state authorities with actual biological resources data and an analysis tool has been stated. The necessity of complex analysis of heterogeneous biological resources data in connection with the landscape factors has been articulated. The system of biological resources' cartographic models (BRCM) is proposed as tools for the regional authorities to develop the BRCM for practical appliances. The goal and the target audience of the system are named. The principles of cartographic visualization of information in the BRCM are formulated. The main sources of biological resources data are listed. These sources include state cadastres, monitoring and statistics. The scales for regional and topical biological resources' cartographic models are stated. These scales comprise two scale groups for depicting the region itself and its units of internal administrative division. The specifics of cartographic modeling and visualization of relief according to legal requirements to public cartographic data are described. Various options of presentation of biological resources' cartographic models, such as digital maps, 3Dmodels and cartographic animation are described. Examples of maps and cartographic 3D-models of Novosibirsk Region forests are shown. The conclusion about practical challenges solved with BRCM has been made.
\end{abstract}

\section{KEYWORDS:}

natural resources mapping, biological resources, regional environmental management, environmental governance, cartographic models

\footnotetext{
${ }^{1}$ Siberian State University of Geosystems and Technologies; 630108, Russia, Novosibirsk, Plakhotny st, 10; e-mail: onixx76@mail.ru
} 


\section{REFERENCES}

1. Beshentsev A.N. Geoinformacionnoe obespechenie monitoringa transformacii prirodnyh landshaftov $\mathrm{v}$ bassejne oz. Bajkal na osnove retrospektivnyh kartograficheskih materialov [Geoinformational support for monitoring transformation of natural landscapes in the basin of lake Baikal based on retrospective cartographic materials], Aridnye ekosistemy, 2011, No 4 (49), pp. 53-62 (in Russian).

2. Kotel'nikova N.V., Mazurov S.F., Plastinin L.A. Zadachi geoinformacionnogo obespechenija organov vlasti, hozjajstva, obrazovanija i biznesa v Bajkal'skom regione Sibiri [The tasks of geoinformation support of authority, economy, education and business institutions in the Baikal region of Siberia] // GEO-Sibir': IV Mezhdunar. nauch. kongr.: sb. materialov v 5 t. (Novosibirsk, 22-24 aprelja 2008 g.), Novosibirsk, SGGA, 2008, Vol. 1, Part 2, pp. 133136 (in Russian).

3. Lisickij D.V. Instrumental'naja spravochno-analiticheskaja GIS - novyj geoinformacionnyj instrument dlja shirokogo kruga pol'zovatelej [Reference-analytical GIS tool as a new geoinformation instrument for a wide range of users], Interekspo Geo-Sibir', 2012, Vol. 1, pp. 213-219 (in Russian).

4. Nikolaeva O.N. Ob interaktivnom sozdanii kartograficheskogo obespechenija dlja upravlenija prirodopol'zovaniem [On interactive creation of cartographic support for natural resources management], Teoreticheskie i prikladnye aspekty sovremennoj nauki: sb. nauch. trudov po materialam IX Mezhdunar. Nauchno-prakt. konf., 31 marta 2015 g. / Pod obshh. red. M. G. Petrovoj, Belgorod, IP Petrova M. G., 2015, Part 2, pp. 10-15 (in Russian).

5. Nikolaeva O.N. O razrabotke kartograficheskogo obespechenija dlja effektivnogo upravlenija lesnymi resursami [The development of cartographic application for effective forest management], Geodezija i kartografija, 2015, No 11, pp. 30-34 (in Russian).

6. Rejmers N.F. Prirodopol'zovanie. Slovar'-spravochnik [Environment management. Dictionary directory]. - M., Mysl', 1990, 639 p. (in Russian).

7. Polozhenie o lesnom monitoringe [Regulation on forest monitoring]. Pis'mo Federal'noj sluzhby lesnogo hozjajstva RF ot 29 nojab. 1995 g. № MG-1-17-6/287 [Elektronnyj resurs], http://www.businesspravo.ru/Docum/DocumShow_DocumID_35821.html (in Russian).

8. Polozhenie o lesopatologicheskom monitoringe [Regulation on forest pest monitoring] [Elektronnyj resurs], http://docs.cntd.ru/document/901742572 (in Russian).

9. O porjadke vedenija gosudarstvennogo uchyota, gosudarstvennogo kadastra i gosudarstvennogo monitoringa ob'ektov zhivotnogo mira [On the order of state registration, state cadastre and state monitoring of wildlife]: Postanovlenie Pravitel'stva RF ot 10 nojabrja $1996 \mathrm{~g}$. № 1342, Sobranie zakonodatel'stva Rossijskoj Federacii, 1996, No 47, p. 5335 (in Russian).

10. O porjadke vypolnenija funkcii oficial'nogo statisticheskogo uchyota territorial'nymi upravlenijami Rosrybolovstva [On the order of performing the functions of official statistical territorial administrations Rosrybolovstva] [Elektronnyj resurs]: prikaz Federal'nogo agentstva $\begin{array}{lllllll}\text { po rybolovstvu ot } & 9 & \text { aprelja } & 2013 & \text { g. } & \text { № } & \text { 254, }\end{array}$ http://docs.pravo.ru/document/view/35469838/40903452/ (in Russian).

11. Perechen' ob'ektov mestnosti i elementov soderzhanija topograficheskih kart i planov, zapreshchennyh dlja otkrytogo opublikovanija [A list of terrain objects and elements of the content of topographic maps and plans prohibited for open publication]. Utverzhden prikazom Roskartografii ot 14.12.2000 g. № 181pr. (soglasovan s GSh VS RF, No 320/2/2996 ot 02.11.2000 g.) (in Russian).

12. Osnovnye polozheniya po sozdaniyu i obnovleniyu topograficheskih kart masshtabov 1:10000, 1:25000, 1:50000, 1:100000, 1:200000, 1:500000, 1:1000000 [Basic provisions for the creation and updating of topographic map scales 1:10000, 1:25000, 1:50000, 1:100000, 1:200000, 1:500000, 1:1000000], M., Glavnoe upravlenie geodezii i kartografii pri Sovmine SSSR, 1984, 81 p. (in Russian). 
13. Dyshljuk S.S., Nikolaeva O.N., Romashova L.A. Nauchno-metodicheskie osnovy formalizacii processov sostavlenija tematicheskih kart dlja realizacii instrumental'noj spravochnoanaliticheskoj geoinformacionnoj sistemy [Methodological basis for formalization of thematic map-making processes for information-and-reference analytical GIS implementation], Vestnik SGGA, 2011, Vol. 1 (14), pp. 49-54 (in Russian).

14. Nikolaeva O.N. Ob algoritmizacii proektirovanija oformlenija tematicheskih kartograficheskih proizvedenij (na primere kartograficheskih modelej prirodnyh resursov) [On thematic map design algorithmization: a case study of natural resources map-models' development for general public], Vestnik SGUGiT, 2015, Vol. 4 (32), pp. 61-69 (in Russian).

15. Nikolaeva O.N. O proektirovanii tematicheskogo soderzhanija sistemy cifrovyh kartograficheskih modelej prirodnyh resursov regiona [On developing thematic content for the system of natural resources' digital carthographic models of the region], Geodezija i kartografija, 2016, No 7, pp. 33-38 (in Russian).

\section{Н.С. Калюжная ${ }^{1}$, И.Ю. Калюжная ${ }^{2}$, В.В. Хоружая ${ }^{1}$, В.В. Самотеева ${ }^{1}$, Э.Н. Сохина ${ }^{1}$ ОПЫТ ИЗУЧЕНИЯ СОСТОЯНИЯ НЕРЕСТИЛИЩ ВЕРХНЕГО ПЛЁСА ЦИМЛЯНСКОГО ВОДОХРАНИЛИЩА С ИСПОЛЬЗОВАНИЕМ ГИС}

\section{АННОТАЦИЯ}

В статье рассматривается опыт использования ГИС-технологий для изучения состояния и динамики нерестовых угодий на примере Цимлянского водохранилища (в гранищах Волгоградской области) - одного из крупнейших внутренних водоёмов рыбохозяйственного значения на юге России.

Нерестовые угодья рассматривались с позищий концепщии экотонной природы зоньл контакта «вода-суша», отличающейся повышенной флуктуачионной активностью среды, где периодическое затопление является определяющим фактором разнообразия нерестовых биотопов, условий воспроизводства и продуктивности экосистем.

По результатам обработки и дешифрирования космических снимков Landsat на весенний и меженный периоды 2005-2016 га. и сопоставления их с другими материалами (крупномасштабные топографические карты, данные рыбохозяйственных исследований, научные публикации) уточнены гранищы и площади основных нерестовых угодий и их мелиорированных участков на Верхнем плёсе водохранилищза.

На примере трёх модельных участков, расположенных в левобережной части Верхнего плёса, вылелены основные природные и антропогенные факторы, определяющие состояние нерестилищ. Обобщение и анализ ретроспективных данных по составу и урожайности молоди рыб (за период с 1980 г. по настоящее время) подтвердили значимость рассматриваемых участков в естественном воспроизводстве водных биоресурсов и возможность восстановления их рыбохозяйственного потенциила посредством мелиорачии.

Составлены карты, отображаюшие размещение выявленных угодий и факторов, непосредственно или косвенно оказывающих влияние на их состояние. Определень наиболее напряжённые в экологическом отночении участки с широким развитием процессов абразии,

\footnotetext{
${ }^{1}$ Волгоградское отделение ФГБНУ «Государственный научно-исследовательский институт озёрного и речного рыбного хозяйства»; 400001, Россия, Волгоград, ул. Пугачёвская, 1; e-mail:voniorkh@ mail.ru; nskrcb@yandex.ru

${ }_{2}^{2}$ Московский государственный университет имени М.В. Ломоносова, географический факультет; 119991 ,

Россия, Москва, Ленинские Горы, 1; e-mail: kalioujnaia@yandex.ru
} 